Article

\title{
An Empirical Study on the Impact of Foreign Strategic Investment on Banking Sustainability in China
}

\author{
Wanping Yang ${ }^{1}$, Bingyu Zhao ${ }^{1, *}$, Jinkai Zhao ${ }^{1}$ and Zhengda $\mathrm{Li}^{2, *}$ \\ 1 School of Economics and Finance, Xi'an Jiaotong University, Xi'an 710061, China; \\ wanpingyang@mail.xjtu.edu.cn (W.Y.); jinkaizhao@stu.xjtu.edu.cn (J.Z.) \\ 2 School of Management, Xi'an University of Architecture and Technology, Xi'an 710055, China \\ * Correspondence: zby0413@stu.xjtu.edu.cn (B.Z.); lizhengda@xauat.edu.cn (Z.L.)
}

Received: 21 November 2018; Accepted: 24 December 2018; Published: 1 January 2019

\begin{abstract}
In order to improve the banking sustainability in China, China's government has announced that the restrictions on foreign shareholding ratio in domestic banks will be canceled. However, the effectiveness of foreign strategic investment needs checking. In addition, under the new policy, the method by which banks formulate appropriate internal decisions about introducing foreign strategic investment is an important issue for bank managers. Continuous productivity growth will bring sustainable development; therefore, the aims of this paper are: (1) to find the relationship between foreign strategic investment and productivity change of China's banks, and to verify the effectiveness of introducing foreign strategic investment; (2) to find the optimal foreign shareholding ratio; (3) to show how foreign strategic investment affects the productivity of China's banks, i.e. the transmission mechanism between them, and to provide bank managers with evidence and support for making decisions on introduction of foreign strategic investment. This paper employs the Malmquist-Luenberger index and combines it with Epsilon-based-measure to derive a new index, i.e. the EBM-Malmquist-Luenberger index, to measure the dynamic productivity change of China's banks. In addition, the dynamic panel data and system GMM estimator are used to analyze the transmission mechanism as well as the impact of foreign strategic investment on the productivity of China's banks. The results revealed three facts. First, when the foreign shareholding ratio increases within a given range, foreign strategic investment continuously improves the productivity and sustainability of China's banks. Second, an inverse N-shaped relation between foreign strategic investment and productivity growth of China's banks is supported, and the optimal foreign shareholding ratio is $20.16 \%$. Last but not least, foreign strategic investment improves the productivity and sustainability of China's banks, mainly through changing scale efficiency. The results of this paper may provide support for policy formulation of China's banks.
\end{abstract}

Keywords: bank productivity; foreign strategic investment; EBM-Malmquist-Luenberger index; transmission mechanism; optimal shareholding ratio; banking sustainability

\section{Introduction}

Since China joined the World Trade Organization (WTO), its banking industry faces fierce global competition. In order to achieve banking sustainability, the government has carried out a series of reforms to the domestic banking industry. The introduction of foreign strategic investment is one of the most significant measures for China's banking reform in recent years. By selling part of the equity of China's banks to foreign strategic investors, long-term and stable cooperation for the benefit and risk sharing between China's banks and foreign strategic investors will be established. On the basis of this cooperation, high-quality capital, advanced technology and management skills could be introduced into China's banks by foreign strategic investors, which may rapidly improve 
China's banking productivity [1-3]. Since continuously rising productivity will bring about sustainable development [4], the policy of introducing foreign strategic investment would benefit China's banks in terms of achieving sustainable development. In other words, the continuous increase in productivity can be used to validate the possibility of achieving sustainable development for China's banks.

To further promote the sustainability and competitiveness of China's banking industry, in 2018, the China's government announced the cancellation of restrictions on the foreign shareholding ratio in Chinese banks (in one China's bank, the shareholding ratio of single foreign strategic investor cannot exceed $15 \%$, and the total shareholding ratio of all foreign strategic investors cannot exceed $25 \%$ ). Some scholars are doubtful about the rationality of this new policy, since they believe foreign strategic investment may have negative impact on the China's banks.

On one hand, in the initial stage of the implementation of this new policy, the foreign shareholding ratio in China's banks is unfettered, and related internal strategic guideline regarding optimal foreign shareholding ratio for individual bank is absent. Under this situation, China's bank managers may introduce a large amount of foreign strategic investment, which would result in a significant increase of the foreign shareholding ratio. Consequently, foreign strategic investors may obtain financial control or exert huge influences on the strategies and operations of China's banks, which would represent a potential threat to domestic financial security [5], and weaken domestic financial stability and banking sustainability [6]. Ultimately, there will be a deviation from the original aim of introducing foreign strategic investment. Therefore, under this new policy, making banking internal policies regarding the optimal foreign shareholding ratio is indispensable and urgent for China's banks.

On the other hand, after the global financial crisis in 2008, foreign strategic investors had successively sold their shareholdings in the China's banks, which exposed vulnerabilities regarding the policy of introducing foreign strategic investment. Some scholars believe that the main purpose of foreign strategic investors to invest in the China's banks is arbitrage, and introducing foreign strategic investment would not bring substantial improvements to China's banking industry [7].

Wang \& Liu (2010) [8] have confirmed the viewpoint that foreign strategic investment may have a negative impact on the sustainable development of China's banks. They used financial indicators including the rate of return on common stockholders' equity, loan-to-deposit ratio, non-performing loan ratio and capital adequacy ratio, to evaluate bank productivity from three aspects of profitability, security and liquidity. By constructing a linear regression model, the impact of introducing foreign strategic investment on the productivity of China's commercial banks was examined. The results showed that foreign strategic investment would have a negative impact on China's banking industry in the short term. Li \& Qiao (2010) [9] used financial indicators including net profit, asset utilization etc., and studied on the productivity change in China's banks through DuPont analysis. They also found that introducing foreign strategic investment is not conducive to the sustainable development of China's banking industry.

From both studies, it can be seen that bank productivity in China was depicted by financial indicators. However, financial indicators have the drawback of one-sidedness, and may be inaccurate due to the distortion of financial data, which ultimately leads to incorrect research results [10]. In addition, there are various differences between banks, such as the risk tolerance of the bank's board and risk profile. These differences will further affect the financial performance of banks. Consequently, financial indicators, especially net profit, are not fair criteria by which to judge the productivity of banks [11]. Therefore, other scholars use more reliable and objective methods to measure bank productivity. For example, He et al. (2010) [2], Liu and Zhang (2013) [3] both used the stochastic frontier approach (SFA) to build the production frontier of China's banks. The productivity of the China's banks was evaluated by measuring the deviation between the production of certain banks and the production frontier. Based on this, the impact of foreign strategic investment on the productivity of China's banks was analyzed. They found that after the introduction of foreign strategic investment, the productivity of China's banks improved, and that the policy of introducing foreign 
strategic investment was beneficial to banking sustainability. Their conclusions are contrary to the results obtained in $[8,9]$.

Although the SFA can measure the productivity of China's banks more accurately, this approach is still questioned because it needs to pre-set the specific form of the frontier function and cannot easily deal with multiple input vs. multiple output relation. The data envelopment analysis (DEA) [12] can effectively overcome the above shortcomings of SFA. DEA is widely used to evaluate bank productivity [13-16]. In the DEA model, there are two methods to measure productivity: radial and non-radial models. The radial model represented by the CCR model [12] is the first DEA model. The non-radial model represented by the SBM model [17] was proposed later. The existing research on evaluating the productivity of banks is also mainly based on the two models [18-22].

Although the CCR and SBM models are favored by scholars, both have some limitations. First, the CCR model requires that all the inputs change in the same proportion, which is obviously contrary to the reality. By using the SBM model, the projected decision making units (DMU) may lose the original proportion of the input because of the slack variable [23]. Secondly, both radial and non-radial models are static models, which cannot reflect the dynamic changes of productivity $[24,25]$. However, scholars are more concerned with dynamic changes of productivity, because continuously rising productivity will bring about sustainable development [4]. Although Qin and He (2013) [26] measured the dynamic change of productivity of China's banks through building the radial DEA-Malmquist index, they did not analyze the impact of introducing foreign strategic investment on the productivity change of China's banks.

In addition, some scholars and experts paid attention to the impact of foreign strategic investment on China's banks. However, they rarely focused on the question of how foreign strategic investment affects the productivity China's banks. Therefore, existing studies may neither provide bank managers with enough assistance and evidence to formulate reasonable internal policies and management decisions about introducing foreign strategic investment, nor help China's banks to achieve sustainability.

In this paper, the Epsilon-based-measure (EBM) [23], which combines the advantages of non-radial and radial models, was employed. Based on this, a new index to measure the productivity change of China's banks, i.e. the EBM-Malmquist-Luenberger index (EML), is built. EML can more accurately measure the productivity change of China's banks since it is able to overcome the drawbacks of the existing methods used frequently, such as financial indicators, SFA and DEA. EML may also be utilized in other research fields concerning dynamic efficiency measurement, such as environmental science. Through using EML, the relation between foreign strategic investment and the productivity change of China's banks is obtained in this study. Because continuous increases in productivity will bring sustainable development [4], this relation lays a sound foundation for verifying the effectiveness of foreign strategic investment, i.e. whether introducing foreign strategic investment will help domestic banks to achieve sustainability or not. On the basis of the relation studied above, the optimal foreign shareholding ratio in China's banks was further revealed. For China's banks, the determination of the optimal foreign shareholding ratio contributes to avoiding financial risk and instability caused by excessive increase in foreign shareholding ratio, and providing empirical evidence to bank managers in making decisions regarding introducing foreign strategic investment. In this paper, the productivity change of China's banks, which is measured by EML, is decomposed into three parts: pure technical efficiency change (PTEC), scale efficiency change (SEC) and technology change (TC). Based on this decomposition, the transmission mechanism, i.e. the ways in which foreign strategic investment affects the productivity of China's banks, was unveiled. The discovery of the transmission mechanism could serve as a reference for the sustainable development of China's banking industry. It would also fill the research gap, since few previous works have studied this issue.

The remainder of this paper is organized as follows. Section 2 outlines the empirical models, the methodology and a description of the data including data sources and definitions of variables. 
Section 3 reports and analyzes the empirical results of models. The final section presents the conclusions, limitations and future perspectives.

\section{Materials and Methods}

\subsection{Productivity Chane of China's Banking Industry}

The outputs of banks not only contain desirable outputs, such as pretax profit, but also include undesirable outputs, such as non-performing loan. Therefore, this paper considers these two types of outputs when measuring the productivity change of China's banks. The directional distance function (DDF) is a relatively new methodology for measuring production efficiency. DDF is proposed by Chambers et al. (1996) [27] and extended by Chung et al. (1997) [28] to environmental efficiency. The traditional DDF is defined to maximize the desirable outputs and reduce the undesirable ones by the same ratio [29]. The Malmquist-Luenberger index (ML), based on the DDF, is used to measure productivity growth which takes both the desirable and undesirable outputs into account [30]. Chung et al. (1997) [28] defined the ML index between period $t$ and $t+1$ as:

$$
M L_{t}^{t+1}=\left(M L_{i}^{t} \times M L_{i}^{t+1}\right)^{\frac{1}{2}}=\left\{\left[\frac{1+\vec{D}_{i}^{t+1}\left(x^{t}, y^{t}, b^{t} ; g^{t}\right)}{1+\vec{D}_{i}^{t+1}\left(x^{t+1}, y^{t+1}, b^{t+1} ; g^{t+1}\right)}\right] \times\left[\frac{1+\vec{D}_{i}^{t}\left(x^{t}, y^{t}, b^{t} ; g^{t}\right)}{1+\vec{D}_{i}^{t}\left(x^{t+1}, y^{t+1}, b^{t+1} ; g^{t+1}\right)}\right]\right\}^{\frac{1}{2}}
$$

The index can be decomposed into two components of productivity:

$$
\begin{aligned}
M L_{t}^{t+1} & =\left\{\left[\frac{1+\vec{D}_{i}^{t+1}\left(x^{t}, y^{t}, b^{t} ; g^{t}\right)}{1+\vec{D}_{i}^{t}\left(x^{t}, y^{t}, b^{t} ; g^{t}\right)}\right] \times\left[\frac{1+\vec{D}_{i}^{t+1}\left(x^{t+1}, y^{t+1}, b^{t+1} ; g^{t+1}\right)}{1+\vec{D}_{i}^{t}\left(x^{t+1}, y^{t+1}, b^{t+1} ; g^{t+1}\right)}\right]\right\}^{\frac{1}{2}} \\
& \times\left\{\left[\frac{1+\vec{D}_{i}^{t}\left(x^{t}, y^{t}, b^{t} ; g^{t}\right)}{1+D_{i}^{t+1}\left(x^{t+1}, y^{t+1}, b^{t+1} ; g^{t+1}\right)}\right]\right\} \\
& =T E C_{t}^{t+1} \times T C_{t}^{t+1}
\end{aligned}
$$

where $M L_{t}^{t+1}$ indicates the productivity change from time $t$ to time $t+1, g$ is the vector of directions in which outputs can be scaled. Following [28], the direction taken is $g=(y,-b), y$ refers to the desirable outputs and $b$ indicates undesirable ones. This direction indicates that the desirable outputs are increased and the undesirable ones are decreased. $\vec{D}_{i}^{t+1}\left(x^{t}, y^{t}, b^{t} ; g^{t}\right)$ is the hybrid directional distance function; it implies the production of time $t+1$ is based on the technology condition of time $t . T E C_{t}^{t+1}$ represents the efficiency change component, and $T C_{t}^{t+1}$ indicates the technical change.

Computing the directional distance functions is the basis of measuring the $M L$ of China's banks. DEA is a data driven tool for measuring the productivity of each DMU, and can be used to compute the directional distance functions [31,32]. In the DEA model, there are two methods to measure productivity: the radial and non-radial models. The radial model, represented by the Charnes-Cooper-Rhodes (CCR) model [12], was the first DEA model. Afterwards, the non-radial model, represented by the slacks-based measure (SBM) model, was proposed. The main shortcoming of radial model is that it requires all the inputs to be reduced by the same proportion. In other words, if the DMU has three inputs, this model aims at obtaining the maximum rate of reduction of all inputs with the same proportion to produce the current outputs [33]. Regarding the key drawback of non-radial model, since the efficient frontier projected by SBM is defined by $\hat{x}_{0}=x_{0}-s^{-*}, x_{0}$ refers to the original input, $s^{-*}$ denotes non-radial slacks. Thus, the projected DMU may lose the original proportion in the $x_{0}$, because $s^{-*}$ is not necessarily proportional to $x_{0}$. If the loss of the original proportionality is improper for the analysis, this becomes a disadvantage of non-radial models [34]. To overcome the shortcomings of the radial and non-radial models, the Epsilon-based measure (EBM) [34] was put forward since this model integrates the advantages of radial and non-radial models in a unified framework. The EBM is defined as follows: 


$$
\begin{gathered}
r^{*}=\min _{\theta, \lambda, s^{-}} \theta-\varepsilon_{x} \sum_{i=1}^{m} \frac{w_{i}^{-} s_{i}^{-}}{x_{i 0}} \\
\theta_{x 0}-X \lambda-s^{-}=0 \\
\text { s.t. } \quad Y \lambda \geq y_{0} \\
\lambda \geq 0, s^{-} \geq 0
\end{gathered}
$$

where $r^{*}$ is the optimal efficiency, $\theta$ is efficiency measured with radial model. $s_{i}^{-}$is slack of input $i, w_{i}^{-}$ is the weight of input $i$ and it reflects the relative importance of $i, w_{i}^{-}$satisfies $\sum_{i=1}^{m} w_{i}^{-}=1\left(w_{i}^{-} \geq 0, \forall i\right)$. $\varepsilon_{x}$ is a key parameter which indicates the relative importance of the non-radial slacks over the radial $\theta$. Parameters $\varepsilon_{x}$ and $w_{i}^{-}$must be supplied prior to the efficiency measurement, and they should be units-invariant values [34].

If EBM is employed to compute DDF, and integrate it with ML, then a new index of measuring productivity change could be obtained, i.e. the EBM-Malmquist-Luenberger index (EML). EML is a new method to measure the productivity change of China's banks. It can conquer the drawbacks of the most frequently used methods such as financial indicators, DEA, SFA. The EML can be defined as follows:

$$
\begin{aligned}
E M L & =\left(M L_{i}^{t} \times M L_{i}^{t+1}\right)^{\frac{1}{2}} \\
& =\left\{\frac{1+\vec{D}_{i}^{t+1}\left(x^{t}, y^{t}, b^{t} ; g^{t}\right)}{1+\vec{D}_{i}^{t+1}\left(x^{t+1}, y^{t+1}, b^{t+1} ; g^{t+1}\right)} \times \frac{1+\vec{D}_{i}^{t}\left(x^{t}, y^{t}, b^{t} ; g^{t}\right)}{1+\vec{D}_{i}^{t}\left(x^{t+1}, y^{t+1}, b^{t+1} ; g^{t+1}\right)}\right\}^{\frac{1}{2}} \\
& =T E C_{t}^{t+1} \times T C_{t}^{t+1}
\end{aligned}
$$

Following [35], the TEC can be further decomposed into pure technical efficiency change (PTEC) and scale efficiency change (SEC). Therefore, Model (4) can be redefined as:

$$
\begin{aligned}
E M L_{t}^{t+1} & =\frac{1+\vec{D}_{V}^{t+1}\left(x^{t+1}, y^{t+1}, b^{t+1} ; y^{t+1}, b^{t+1}\right)}{1+\vec{D}_{V}^{t}\left(x^{t}, y^{t}, b^{t}, y^{t}, b^{t}\right)} \\
& \times\left|\frac{1+\vec{D}_{V}^{t}\left(x^{t}, y^{t}, b^{t}, y^{t}, b^{t}\right)}{1+\vec{D}_{C}^{t}\left(x^{t}, y^{t}, b^{t}, y^{t}, b^{t}\right)} \div \frac{1+\vec{D}_{V}^{t+1}\left(x^{t+1}, y^{t+1}, b^{t+1} ; y^{t+1}, b^{t+1}\right)}{1+\vec{D}_{C}^{t+1}\left(x^{t+1}, y^{t+1}, b^{t+1} ; y^{t+1}, b^{t+1}\right)}\right| \\
& \times\left\{\frac{1+\vec{D}_{C}^{t}\left(x^{t+1}, y^{t+1}, b^{t+1} ; y^{t+1}, b^{t+1}\right)}{1+\vec{D}_{C}^{t+1}\left(x^{t+1}, y^{t+1}, b^{t+1} ; y^{t+1}, b^{t+1}\right)} \times \frac{\vec{D}_{C}^{t}\left(x^{t}, y^{t}, b^{t}, y^{t}, b^{t}\right)}{1+\vec{D}_{C}^{t+1}\left(x^{t}, y^{t}, b^{t}, y^{t}, b^{t}\right)}\right\}^{\frac{1}{2}} \\
& =\operatorname{PTEC} \times \operatorname{SEC} \times T C
\end{aligned}
$$

where $\vec{D}_{V}(\cdot)$ and $\vec{D}_{C}(\cdot)$ indicate the productivity measure exhibiting VRS and CRS, respectively. If $E M L>1$, it denotes that there is productivity growth from the time $t$ to time $t+1$. TEC $>1$ means the technical efficiency is enhanced. Furthermore, regarding the two decomposition components of TEC, PTEC $>1$ denotes business management is improved, SEC $>1$ means economies of scale is obtained. TC $>1$ implies the production frontier is moving outward, which indicates that technological advancement has been achieved.

\subsection{Models}

To examine the relation between foreign strategic investment and productivity changes of China's banks, and then reveal the optimal foreign shareholding ratio, following Lee and Hsieh (2014) [6], this paper establishes the basic model as follows:

$$
E F F_{i, t}=\alpha+\beta E F F_{i, t-1}+\sum_{p} \lambda_{p} F R_{i, t}+\sum_{k} \lambda_{k} Y_{i, t}+\sum_{l} \lambda_{l} X_{i, t}+\sum_{m} \lambda_{m} B_{i, t}+v_{i, t}
$$


where $i=1, \ldots, N ; t=1, \ldots, T ; N$ refers to the bank number; $t$ is for time; $\lambda, \beta$ and $\alpha$ are estimated parameters. The variables are introduced as below; $E F F_{i, t}$ is a set of dependent variables used to measure the change of banking productivity, which is obtained based on the $E M L . F R_{i, t}$ refers to foreign strategic investment, which is represented by foreign shareholding ratio in China's banks per year. Considering that the impact of foreign strategic investment on productivity of China's banks has a dynamic effect, static panel data cannot correctly reflect this effect. In order to address this problem, we introduce a lagged dependent variable $E F F_{i, t-1}$ into the Model (6) as an independent variable.

In order to further determine the authentic relationship between foreign strategic investment and the productivity change of China's banks, this study refers to the method used in [36-38]. Specifically, through adding the quadratic terms of the percentage of lawyers abroad, [36] examined the relation between international diversification and performance of law firms. [37] adopted a similar method to discover the relationship between state ownership and the performance of newly-privatized, Chinese state-owned enterprises. [38] added the quadratic and cubic terms of the logarithm of per capita GDP to discover the relationship between economic growth and pollutant emissions in Tunisia. Following [36-38], this study further establishes Model (7) to Model (10) on the basis of Model (6), which are defined as follows:

$$
\begin{gathered}
E F F_{i, t}=\alpha+\beta E F F_{i, t-1}+\sum_{q} \lambda_{q} F R_{i, t}^{2}+\sum_{k} \lambda_{k} Y_{i, t}+\sum_{l} \lambda_{l} X_{i, t}+\sum_{m} \lambda_{m} B_{i, t}+v_{i, t} \\
E F F_{i, t}=\alpha+\beta E F F_{i, t-1}+\sum_{j} \lambda_{j} F R_{i, t}^{3}+\sum_{k} \lambda_{k} Y_{i, t}+\sum_{l} \lambda_{l} X_{i, t}+\sum_{m} \lambda_{m} B_{i, t}+v_{i, t} \\
E F F_{i, t}=\alpha+\beta E F F_{i, t-1}+\sum_{p} \lambda_{p} F R_{i, t}+\sum_{q} \lambda_{q} F R_{i, t}^{2}+\sum_{k} \lambda_{k} Y_{i, t} \\
+\sum_{l} \lambda_{l} X_{i, t}+\sum_{m} \lambda_{m} B_{i, t}+v_{i, t} \\
E F F_{i, t}=\begin{array}{c}
\alpha+\beta E F F_{i, t-1}+\sum_{p} \lambda_{p} F R_{i, t}+\sum_{q} \lambda_{q} F R_{i, t}^{2}+\sum_{j} \lambda_{j} F R_{i, t}^{3} \\
+\sum_{k} \lambda_{k} Y_{i, t}+\sum_{l} \lambda_{l} X_{i, t}+\sum_{m} \lambda_{m} B_{i, t}+v_{i, t}
\end{array}
\end{gathered}
$$

where $Y, X$ and $B$ refer to the control variables of macro level, industry level and micro level respectively. Referring to Ji and Kong (2010) [39], Liu and Nie (2016) [40], the control variables of macro level include GDP growth rate $\left(G G D P_{t}\right)$ and the consumer price index $\left(C P I_{t}\right)$; control variables of industry level

\begin{tabular}{|c|c|c|}
\hline & Variable & Description \\
\hline Dependent variable & $E F F_{i, t}$ & Productivity change of China's banks which is calculated based on $E M L$ \\
\hline \multirow[t]{2}{*}{ Independent variable } & $F R_{i, t}$ & Foreign shareholding ratio per year \\
\hline & $E F F_{i, t-1}$ & $\begin{array}{l}\text { The lagged dependent variable which means the productivity change of } \\
\text { China's banks in time } t-1\end{array}$ \\
\hline \multicolumn{3}{|l|}{ Control variables } \\
\hline \multirow[t]{2}{*}{ Macro level } & $G G D P_{t}$ & GDP growth rate of time $t$ \\
\hline & $C P I_{t}$ & The consumer price index of time $t$ \\
\hline Industry level & $H H I_{i, t}$ & $\begin{array}{l}\text { Herfindahl-Hirschman index of bank } i \text { in time } t \text {, which indicates the } \\
\text { market concentration rate of bank } i\end{array}$ \\
\hline Micro level & $L E V_{i, t}$ & The asset-liability ratio of bank $i$ in time $t$ \\
\hline
\end{tabular}
include market concentration rate, which is indicated by the Herfindahl-Hirschman index $\left(H H I_{i, t}\right)$ of banks [41]; control variables of micro level include the asset-liability ratio $\left(L E V_{i, t}\right)$ [41]. Additionally, $v_{i, t}$ is an error term.

The definitions for all variables are presented in Table 1.

Table 1. Variable definitions. 
This paper employs a dynamic panel data model and system GMM to examine the relation of foreign strategic investment to productivity change of China's banks. In the dynamic panel data model, the lagged dependent variable is used as one independent variable; this causes endogeneity. Estimating a dynamic panel data model using traditional approaches, such as the least-square method, will result in biased estimations. To solve this problem, Holtz-Eakin et al. (1988) [42], Arellano and Bond (1991) [43] proposed difference GMM. Although the difference GMM can effectively solve the problem of endogeneity, this measure may still result in biased estimations [44]. To overcome the shortcomings of difference GMM, Blundell and Bond (1998) [44] further proposed a system GMM which was found to be more efficient [44]. Moreover, this paper applies the Sargan test to verify the validity of the instrumental variables, since too many instrumental variables will result in biased estimations.

\subsection{Sample and Sources of Data}

This paper investigates the impact of foreign strategic investment on the productivity of China's banks by using panel data covering 41 listed banks in China for 2004-2017, which include 6 large state-owned banks, 9 joint-equity banks, 18 city commercial banks and 8 rural commercial banks. The start year of this paper is 2004 since on December 31, 2003, China's government permitted foreign strategic investment to be introduced into domestic banks.

To calculate the $E M L$, the related input and output indicators are as follows: Input indicators include net value of fixed assets, number of employees, staff wage payment and other cash payment related to operating activities. In addition, Drake et al. (2006) [45] discovered that ignoring operational risk of banks will lead to inaccurate measurements of bank productivity. Therefore, general risk preparation is also employed as another input indicator.

In respect of output of China's banks, as mentioned earlier, it includes desirable outputs and undesirable ones. Specifically, in this paper, desirable outputs contain profit before tax and non-interest income. Following [46], non-performing loans have a significant negative impact on bank performance; therefore, in this paper, non-performing loans are used as the undesirable output of China's banks. If a bank does not have non-performing loans in time $t$, the average non-performing loan can be used to represent it. In detail, the mean of the non-performing loan ratio of time $t-1$ and time $t+1$ is used as the non-performing loan ratio for the time $t$; this is then multiplied by the total loan of time $t$ to represent the missing data.

The data of this paper originates from Wind database [47], Almanac of China's Finance and Banking and manual calculation by authors.

\section{Results and Discussion}

\subsection{Productivity Change of China's Banks and the Implications}

According to the new index EML built in this paper, we acquired the calculation result of productivity change of China's banks for 2004-2017, which is presented in Table 2. The results show that since implementing the policy of introducing foreign strategic investment, the productivity of China's banks has increased by $4.27 \%$ per year in average. This continuous productivity growth would be beneficial to achieve sustainable development for China's banks. The main reason for this growth is technical change (TC), which increases by $3.59 \%$ annually on average. This may be because of the rapid technical development in China. In addition, as mentioned above, SEC and PTEC are the two decomposition components of TEC. From Table 2, TEC increases by $0.66 \%$ per year on average, SEC by $1.25 \%$ annually, but PTEC declines by $0.1 \%$ per year. PTEC means an increase of productivity through innovation and management improvement under the same production technique. Innovation and management improvements are the driving forces for the growth of productivity [35]. Therefore, a decrease of PTEC implies a shortage of core power for improving banking productivity, which results in the deficiency of motivation of sustainability of China's banks. 
Table 2. Productivity change of China's banks.

\begin{tabular}{cccccc}
\hline Bank Type & TC & TEC & PTEC & SEC & EML \\
\hline Large state-owned banks & 1.0351 & 1.0027 & 0.9907 & 1.0121 & 1.0379 \\
Joint-equity banks & 1.0548 & 1.0103 & 0.9949 & 1.0155 & 1.0657 \\
City commercial banks & 1.0283 & 1.012 & 0.994 & 1.0182 & 1.0406 \\
Rural commercial banks & 1.0255 & 1.0013 & 0.9819 & 1.0044 & 1.0268 \\
All Sample banks & 1.0359 & 1.0066 & 0.9904 & 1.0125 & 1.0427 \\
\hline
\end{tabular}

Note: data were the calculation results by EML index built in this paper.

In respect of the productivity change of four types of China's banks, all of them have continuous increases in productivity every year. Specifically, joint-equity bank has the best productivity improvement, city commercial bank comes second, followed by large state-owned banks and rural commercial banks. The productivity of joint-equity banks increases by $6.57 \%$ annually; this may be determined by their features. In detail, joint-equity banks establish corporate governance structures earlier than other types of bank in China. Thus, there exists relatively sound internal system of mutual supervision, checks and balances in joint-equity banks [48]. Additionally, the growth rate of productivity of large state-owned banks and rural commercial banks are $3.79 \%$ and $2.68 \%$ respectively, which are both lower than the growth rate $(4.06 \%)$ of city commercial banks. The main reason for the higher growth rate of productivity in city commercial banks may be their relatively large business scale. In China, city commercial banks are located in various regions. This feature of city commercial banks is beneficial to expanding their market influence and increasing their market share, which would assist in the promotion of productivity and sustainability.

\subsection{The Relation of Foreign Strategic Investment to the Productivity Change of China's Banks, and Associated Implications}

As mentioned above, the results of EML in Table 2 show that the productivity of China's banks is continuously growing. Furthermore, we estimate the impact of foreign shareholding ratio on the productivity growth of China's banks based on the Model (6) to (10). The estimated results are reported in Table 3.

As shown in Table 3, the corresponding variables of $F R_{i, t}$ in Model (6), Model (7) and Model (9) are not significant. However, the corresponding variables of $F R_{i, t}$ in Model (8) and Model (10), which include $F R^{3}{ }_{i, t}$, are all significant. In addition, in Model (10), the coefficients of $F R_{i, t}$ and $F R^{3}{ }_{i, t}$ are both negative, whereas for $F 2^{3}{ }_{i, t}$, the coefficient is positive. Following [36,38], the above results imply there is an inverse $\mathrm{N}$-shaped relation between foreign shareholding ratio and productivity growth of China's banks, which is depicted in Figure 1.

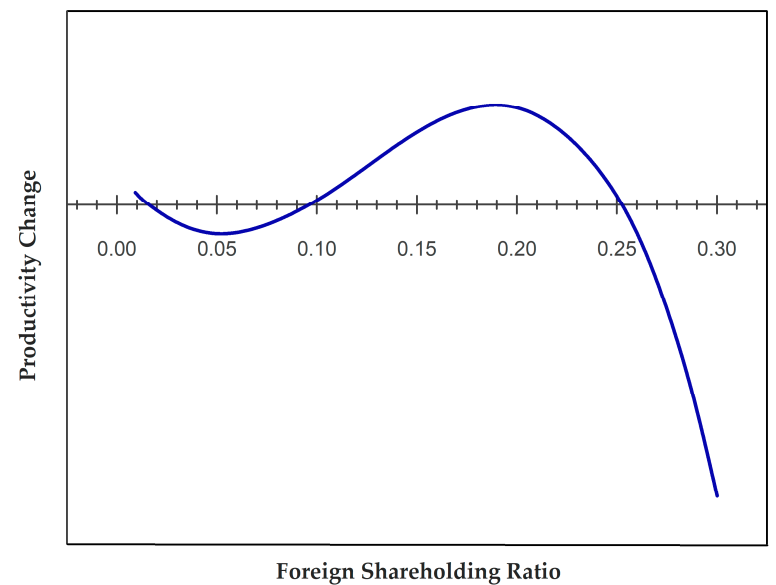

Figure 1. Relation between foreign shareholding ratio and productivity growth of China's banks. Source: manual calculation. 
Table 3. Estimated results of the impact of foreign shareholding ratio on productivity change of China's banks.

\begin{tabular}{|c|c|c|c|c|c|}
\hline Variables & Model (6) & Model (7) & Model (8) & Model (9) & Model (10) \\
\hline L1-Dependent & $\begin{array}{c}-0.17^{* * *} \\
(-5.66)\end{array}$ & $\begin{array}{l}-0.14^{* * *} \\
(-4.78)\end{array}$ & $\begin{array}{c}-0.16^{* * *} \\
(-5.25)\end{array}$ & $\begin{array}{c}-0.15^{* * *} \\
(-5.11)\end{array}$ & $\begin{array}{c}-0.15^{* * *} \\
(-5.11)\end{array}$ \\
\hline$F R$ & $\begin{array}{c}-0.62 \\
(-0.55) \\
\end{array}$ & / & $\begin{array}{l}1 \\
1\end{array}$ & $\begin{array}{c}-0.75 \\
(-1.23) \\
\end{array}$ & $\begin{array}{l}-0.71 * \\
(-1.87)\end{array}$ \\
\hline$F R^{2}$ & / & $\begin{array}{c}9.55 \\
(1.52) \\
\end{array}$ & $\begin{array}{l}1 \\
1\end{array}$ & $\begin{array}{c}8.89 \\
(1.60)\end{array}$ & $\begin{array}{l}9.13 * \\
(1.96)\end{array}$ \\
\hline$F R^{3}$ & $\begin{array}{l}1 \\
1\end{array}$ & I & $\begin{array}{c}-221.02 * * * \\
(-12.56)\end{array}$ & I & $\begin{array}{c}-178.25^{* * *} \\
(-10.15)\end{array}$ \\
\hline GGDP & $\begin{array}{l}2.15^{*} \\
(1.72)\end{array}$ & $\begin{array}{l}2.24 * \\
(1.75)\end{array}$ & $\begin{array}{l}2.33^{*} \\
(1.80)\end{array}$ & $\begin{array}{l}2.11 * \\
(1.76)\end{array}$ & $\begin{array}{l}2.62 * \\
(1.83)\end{array}$ \\
\hline$C P I$ & $\begin{array}{l}9.51 * \\
(1.76)\end{array}$ & $\begin{array}{l}8.78^{*} \\
(1.77)\end{array}$ & $\begin{array}{l}9.74 * \\
(1.80)\end{array}$ & $\begin{array}{l}9.45^{*} \\
(1.82)\end{array}$ & $\begin{array}{l}9.03 * \\
(1.78)\end{array}$ \\
\hline$H H I$ & $\begin{array}{l}-23.45^{*} \\
(-1.88)\end{array}$ & $\begin{array}{l}-20.12 * * \\
(-2.21)\end{array}$ & $\begin{array}{c}-22.44 * * \\
(-2.34)\end{array}$ & $\begin{array}{l}-21.32 * * \\
(-2.09)\end{array}$ & $\begin{array}{c}-21.86^{* *} \\
(-2.16)\end{array}$ \\
\hline$L E V$ & $\begin{array}{l}-2.85 \\
(-1.45)\end{array}$ & $\begin{array}{l}-2.56 \\
(-1.63)\end{array}$ & $\begin{array}{l}-2.42 * \\
(-1.67)\end{array}$ & $\begin{array}{l}-2.55^{*} \\
(-1.70)\end{array}$ & $\begin{array}{l}-2.76 \\
(-1.48)\end{array}$ \\
\hline Abond (1) test & $\begin{array}{l}-1.10 \\
{[0.27]}\end{array}$ & $\begin{array}{l}-1.04 \\
{[0.28]}\end{array}$ & $\begin{array}{l}-1.14 \\
{[0.25]}\end{array}$ & $\begin{array}{l}-1.16 \\
{[0.24]}\end{array}$ & $\begin{array}{l}-1.14 \\
{[0.24]}\end{array}$ \\
\hline Abond (2) test & $\begin{array}{c}1.05 \\
{[0.29]}\end{array}$ & $\begin{array}{c}1.03 \\
{[0.30]}\end{array}$ & $\begin{array}{l}-1.05 \\
{[0.19]}\end{array}$ & $\begin{array}{l}-1.05 \\
{[0.11]}\end{array}$ & $\begin{array}{l}-1.04 \\
{[0.11]}\end{array}$ \\
\hline Sargan test Chi2(n) & $\begin{array}{l}28.09 \\
{[1.00]}\end{array}$ & $\begin{array}{l}25.60 \\
{[1.00]}\end{array}$ & $\begin{array}{l}27.93 \\
{[1.00]}\end{array}$ & $\begin{array}{l}25.09 \\
{[1.00]}\end{array}$ & $\begin{array}{l}26.52 \\
{[1.00]}\end{array}$ \\
\hline
\end{tabular}

Note: L1-Dependent, $F R, F R^{2}$ and $F R^{3}$ are independent variables, L1-Dependent is a lagged dependent variable. $G G D P, C P I, H H I$ and $L E V$ are control variables. T statistics is in parentheses. Abond (1) test and Abond (2) test indicate first order autocorrelation test and second order autocorrelation test, respectively. Z-value is in the square bracket. ${ }^{* * *}$ indicates $p<0.01,{ }^{* *}$ indicates $p<0.01,{ }^{*}$ indicates $p<0.1$.

As shown in Figure 1, extremely high or low foreign shareholding ratio both would weaken bank productivity and hamper the realization of sustainable development of China's banks. The reasons for this may be as follows: First, when the foreign shareholding ratio is low, the cost of supervision is higher than profit owned by foreign investors; thus, foreign strategic investors will not dedicate themselves to bank management. Second, Unite and Sullivan (2003) [49] found that most banks introduce first foreign strategic investment at the beginning period of equity and corporate governance reform. The reason for this is the banks are more concerned about business scale and expansion speed during that period, both of which need more capital to invest in. Thus, the banks may introduce a large amount of foreign strategic investment. As the foreign strategic investment increases, the foreign strategic investors may make the right of making decisions. This may cause the domestic banks to be involved in new businesses which are beneficial to the foreign strategic investors. However, the new businesses usually do not make profit instantly, since they are new fields that China's banks have not dealt with before. The shortage of related management skills and experience may result in losses. Consequently, total profit and productivity of the banks will decline [8]. In addition, when the foreign shareholding ratio is very high, foreign strategic investors and the bank management may have conflicts about business scope and operations; this may also weaken bank productivity [7]. Lastly, the main aim of introducing a large amount of foreign strategic investment to China's banks is usually to acquire advanced knowledge and technologies from foreign strategic investors, which will increase operating costs and temporarily decrease bank productivity [26].

The estimated results also present that financial industry and the national economy are mutually dependent. Specifically, national economic growth could lay the foundation for the development of domestic financial industry. Additionally, there is a negative correlation between the HHI and productivity growth of China's banks. This implies that the higher market concentration, the lower 
the productivity growth of China's banks. This illustrates that overprotecting banking industry is inadvisable, and that market competition is beneficial to the sustainable development of China's banks. The control variable $L E V$ is not significant, which implies that different debt levels exert different effects on the productivity of China's banks.

\subsection{The Optimal Foreign Shareholding Ratio of China's Banks, Effectiveness of Introducing Foreign Strategic} Investment and the Implications

As mentioned earlier, there is an inverse $\mathrm{N}$-shaped relation between foreign shareholding ratio and productivity growth of China's banks. As shown in Figure 1, there are two inflection points which are $5.11 \%$ and $20.16 \%$, respectively. The two inflection points mean that the productivity growth of China's banks would reach a minimum when the foreign shareholding ratio is $5.11 \%$, and reach a maximum when the ratio is $20.16 \%$. Figure 1 also shows that bank productivity growth decreases when the foreign shareholding ratio is lower than $5.11 \%$ or higher than $20.16 \%$, and increases when the ratio is between $5.11 \%$ and $20.16 \%$. This implies that when the foreign shareholding ratio in China's banks increases to within the range, i.e., $5.11 \%$ to $20.16 \%$, the foreign strategic investment contributes to maintaining continuous growth in the productivity of China's banks. Thus, to achieve sustainability, domestic bank managers should maintain a foreign shareholding ratio in the range of $5.11 \%$ to $20.16 \%$.

More importantly, when the foreign shareholding ratio is $20.16 \%$, the productivity growth of China's banks reaches the maximal value, which implies the optimal foreign shareholding ratio is $20.16 \%$. Therefore, to realize the fastest productivity growth, improve the international competitiveness and achieve sustainable development, domestic bank managers should limit the foreign shareholding ratio to around $20.16 \%$. To bank managers in China, this result may provide evidence by which to formulate internal policies regarding the introduction of foreign strategic investment.

Additionally, an inverse $\mathrm{N}$-shaped relation between foreign shareholding ratio and productivity growth of China's banks implies that the foreign shareholding ratio remaining and increasing in a reasonable range would effectively promote the growth rate of productivity of China's banks. In other words, foreign strategic investment in a proper range is beneficial to maintaining and improving the sustainable development of China's banks. This verifies the effectiveness of introducing foreign strategic investment.

\subsection{The Transmission Mechanism Between Foreign Strategic Investment and Productivity of China's Banks, and the Implications thereof.}

As mentioned in Section 2, EML illustrates the productivity change of China's banks. EML can be decomposed into TC and TEC; furthermore, the TEC can be decomposed into PTEC and SEC. Thus, $P T E C, S E C$ and TC can be treated as the driving factors of productivity change for China's banks. In order to determine how foreign strategic investment affects productivity of China's banks, i.e. the transmission mechanism between foreign strategic investment and productivity of China's banks, we estimated the impact of foreign shareholding ratio on each of the decomposition components (PTEC, SEC and TC) of EML with system GMM. The related regression models applied to examine the transmission mechanism are Model 1 to Model 6, which are based on Model (10) in Section 2. The only difference between Model (10) and the models used here is the independent variable. In Models 1 to 6, the corresponding independent variables are TC, TEC, PTEC, SEC, TEC $\times$ PTEC and $T E C \times S E C$, respectively.

According to the estimated results in Table 4, the corresponding variables of $F R_{i, t}$ in Model 1 are not significant. This implies that foreign strategic investment has no significant impact on $T C$, which could be explained by the decline of dependence on foreign strategic investors in terms of advanced technologies. Technical change (TC) refers to the acquisition of advanced production technologies which promote the productivity of China's banks. In recent years, instead of being introduced by foreign strategic investors, China has developed many advanced production 
technologies independently, such as artificial intelligence. Therefore, foreign strategic investment has no significant impact on TC [50].

Table 4. Estimated results of the transmission mechanism between foreign strategic investment and the productivity of China's banks.

\begin{tabular}{ccccccc}
\hline Variables & Model 1 & Model 2 & Model 3 & Model 4 & Model 5 & Model 6 \\
\hline $\begin{array}{c}\text { Dependent } \\
\text { variables }\end{array}$ & $T C$ & TEC & PTEC & SEC & TEC $\times$ PTEC & TEC $\times$ SEC \\
\hline \multirow{2}{*}{ L1-Dependent } & $-0.42^{*}$ & $-0.35^{* * *}$ & $-0.45^{*}$ & $-0.29^{* *}$ & $-0.15^{*}$ & $-0.51^{* * *}$ \\
& $(-1.71)$ & $(-3.23)$ & $(-1.91)$ & $(-2.45)$ & $(-4.66)$ & $(-3.97)$ \\
\hline \multirow{2}{*}{$F R$} & -0.44 & $-0.66^{*}$ & -0.66 & $-0.77^{* * *}$ & -0.38 & $-0.68^{* * *}$ \\
& $(-1.17)$ & $(-1.77)$ & $(-1.37)$ & $(-1.99)$ & $(-1.37)$ & $(-2.13)$ \\
\hline \multirow{2}{*}{$F R^{2}$} & 6.22 & $7.25^{*}$ & $5.13^{*}$ & $8.69^{*}$ & 5.87 & $8.88^{*}$ \\
& $(1.26)$ & $(1.96)$ & $(1.66)$ & $(1.95)$ & $(1.61)$ & $(1.78)$ \\
\hline \multirow{2}{*}{$F R^{3}$} & -155.52 & $-188.25^{* * *}$ & -122.53 & $-179.82^{* * *}$ & -109.65 & $-170.69^{* * *}$ \\
& $(-1.15)$ & $(-8.62)$ & $(-1.44)$ & $(-9.37)$ & $(-1.67)$ & $(-6.93)$ \\
\hline \multirow{2}{*}{ GGDP } & $1.99^{*}$ & $2.22^{*}$ & 1.62 & $2.56^{* *}$ & $2.42^{*}$ & $2.67^{*}$ \\
& $(1.83)$ & $(1.77)$ & $(1.63)$ & $(2.23)$ & $(1.88)$ & $(1.873)$ \\
\hline \multirow{2}{*}{ CPI } & 7.25 & 7.66 & 8.14 & $9.23^{*}$ & $8.55^{*}$ & $9.11^{*}$ \\
& $(1.08)$ & $(1.24)$ & $(1.09)$ & $(1.78)$ & $(1.68)$ & $(1.77)$ \\
\hline \multirow{2}{*}{$H H I$} & $-12.36^{* *}$ & $-15.78^{*}$ & $-19.33^{*}$ & $-17.51 * *$ & $-16.65^{*}$ & $-18.46^{* *}$ \\
& $(-2.02)$ & $(-1.76)$ & $(-1.96)$ & $(-2.22)$ & $(-1.77)$ & $(-2.10)$ \\
\hline \multirow{2}{*}{ LEV } & -1.55 & -1.62 & -1.52 & -1.98 & -1.63 & -1.88 \\
& $(-1.48)$ & $(-1.02)$ & $(-1.36)$ & $(-1.45)$ & $(-1.43)$ & $(-1.52)$ \\
\hline \multirow{2}{*}{ Abond(1) Test } & -1.54 & -1.32 & -1.31 & -1.66 & -1.46 & -1.27 \\
\hline \multirow{2}{*}{ Abond(2) Test } & {$[0.36]$} & {$[0.33]$} & {$[0.40]$} & {$[0.32]$} & {$[0.29]$} & {$[0.43]$} \\
\hline \multirow{2}{*}{ Test Chi2(n) } & -1.11 & -1.27 & -1.22 & -1.21 & -1.26 & -123 \\
& {$[0.18]$} & {$[0.18]$} & {$[0.16]$} & {$[0.12]$} & {$[0.14]$} & {$[0.16]$} \\
\hline \multirow{2}{*}{ Norgan } & 33.62 & 36.44 & 35.88 & 31.98 & 34.56 & 32.19 \\
& {$[1.00]$} & {$[1.00]$} & {$[1.00]$} & {$[1.00]$} & {$[1.00]$} & {$[1.00]$} \\
\hline
\end{tabular}

Note: $L 1$-Dependent, $F R, F R^{2}$ and $F R^{3}$ are independent variables, L1-Dependent is a lagged variable. GGDP, CPI, HHI and $L E V$ are control variables. Abond (1) test and Abond (2) test indicate first order autocorrelation test and second order autocorrelation test, respectively. T statistics is in parentheses. Z-value is in the square bracket. *** indicates $p<0.01,{ }^{* *}$ indicates $p<0.01,{ }^{*}$ indicates $p<0.1$.

The corresponding variables of $F R_{i, t}$ in Model 2 are significant; they indicate that foreign strategic investment has an impact on TEC. TEC is constituted by SEC and PTEC. In order to analyze the relation among PTEC, SEC and foreign shareholding ratio, we built Models 3 and 4 by treating PTEC and $S E C$ as corresponding dependent variables respectively, and establish Models 5 and 6 by treating the $T E C \times P T E C$ and the TEC $\times$ SEC as corresponding dependent variables of the two models.

The corresponding variables of $F R_{i, t}$ in Models 4 and 6 are significant; they indicate that foreign strategic investment improves the productivity of China's banks mainly through affecting their scale efficiency. Therefore, the scale efficiency is the principal path to improving the sustainability of China's banks by foreign strategic investment. The reasons for this are as follows: First, foreign strategic investment may enlarge the business scale of China's banks. Furthermore, a larger banking business scale will result in better management innovation and a synergistic effect. Consequently, productivity will increase [51,52]. In addition, foreign strategic investment will actively promote the cross-regional business of China's banks, which will enhance the market share of banks and make more profit for banks. As a consequence, the productivity of China's banks is improved [53]. Lastly, foreign strategic investors will pay more attention to the production and operation of China's banks, which will improve operating efficiency. As a result, the productivity of banks would improve. 


\section{Conclusions, Limitations and Future Perspectives}

\subsection{Conclusions}

To achieve China's banking sustainability, in 2018, China's government announced the cancellation of the restrictions on foreign shareholding ratios in domestic banks. This new policy has been questioned by some Chinese scholars. This is because introducing foreign strategic investment may not be beneficial to the productivity of China's banks, and may not achieve banking sustainability. In addition, unlimited increases of foreign strategic investment of China's banks may undermine the stability and security of national financial system. Therefore, the effectiveness of introducing foreign strategic investment needs to be examined. Internal policies of domestic banks concerning the introduction of foreign strategic investment are needed. For these aims, this paper builds a new index to measure productivity changes of China's banks, i.e. the EBM-Malmquist-Luenberger index (EML). EML would overcome the shortcomings of the most frequently-used methods such as financial indicators, SFA and DEA, and it may also be used in other research areas regarding dynamic efficiency measurement, such as environmental science. Based on EML, with system GMM and dynamic panel data, the relationship between foreign strategic investment and productivity change of China's banks is examined. On the basis of the relation and EML, this paper further verifies the effectiveness of foreign strategic investment, and reveals the optimal foreign shareholding ratio, as well as the ways in which foreign strategic investment affects the productivity of China's banks, i.e. the transmission mechanism between them. Specifically, the findings of this study are as follows:

(1) The productivity of China's banks is constantly increasing; the growth rate is $4.27 \%$ per year in average. An inverse N-shaped relation between foreign shareholding ratio and productivity growth of China's banks is supported. There are two inflection points in this relationship: $5.11 \%$ and $20.16 \%$. This implies that when the foreign shareholding ratio in China's banks increases to within this range, the foreign strategic investment contributes to maintaining continuous growth in the productivity of China's banks. This result proves the effectiveness of introducing foreign strategic investment. It also provides domestic bank managers with empirical evidence, which contributes to formulating internal policy regarding the introduction of foreign strategic investment in China's banks.

(2) The productivity growth of China's banks is minimum when the foreign shareholding ratio is $5.11 \%$, and maximum when foreign shareholding ratio is $20.16 \%$. Therefore, the optimal foreign shareholding ratio is $20.16 \%$. This result reveals that if domestic bank managers limit the foreign shareholding ratio to around $20.16 \%$, China's banks would achieve the fastest growth and realize sustainability. This result can also provide empirical evidence for formulating internal policy regarding introducing foreign strategic investment in China's banks.

(3) Based on EML, the transmission mechanism between foreign strategic investment and productivity change of China's banks is revealed. It fills the research gap since, to the best of our knowledge, very few existing works have studied this issue. In this study, the productivity change of China's banks can be decomposed into three components: purely technical efficiency change (PTEC), scale efficiency change (SEC) and technology change (TC), which are the driving forces of productivity growth. Foreign strategic investment improves the productivity of China's banks mainly through affecting banks' scale efficiencies. Therefore, the scale efficiency is the main path to improving the sustainability of China's banks by foreign strategic investment. This result implies that China's banks, which have introduced or plan to introduce foreign strategic investment, should use foreign capital to enlarge their business scale, encourage management innovation, expand marketing share and improve operation; then, their scale efficiency would be improved. As a result, continuous productivity growth and banking sustainability would be obtained. In addition, this discovery may facilitate the formulation of bank internal policies about introducing foreign strategic investment, and provide a reference for the sustainable development of China's banking industry. 


\subsection{Limitations and Future Perspectives}

There may be some limitations in this study. On the one hand, it does not take the differences among bank types into consideration. Different types of banks differ greatly in their aims and attitudes towards introducing foreign strategic investment. Therefore, the general conclusions of this study may be not applicable to all the types of banks. On the other hand, this study does not consider the international environment such as the economic or political environment. The control variables of macro level in this study are only GDP and CPI in China. However, because of globalization, changes in the international environment will have significant effects on almost all the fields of a country including financial area. Therefore, control variables which represent aspects of the international environment should be considered. In future, when the new policy of cancelling the restriction on foreign shareholding ratio in domestic banks is fully implemented, researchers can select data to test the conclusions of this study. Furthermore, future work could focus on the effectiveness of this new policy. This kind of future work will be of far-reaching practical significance for achieving sustainable development in the banking industry in China.

Author Contributions: W.Y. analyzed the data and wrote the paper; B.Z. designed the research framework, analyzed the data and wrote the paper; J.Z. revise the grammar of this paper; Z.L. designed the research framework and participated in the revision of the paper.

Funding: Our work was supported by National Social Science Foundation in China (No. 17BJL043).

Acknowledgments: Our work was supported by National Social Science Foundation in China (No. 17BJL043). We thank Dr. Kai Zhao, who works at the School of Economics and Finance, Xi'an Jiaotong University, for valuable discussion and assistance with the revision work.

Conflicts of Interest: The authors declare no conflict of interest.

\section{References}

1. Malik, A.; Thanh, N.; Shah, H. Effects of ownership structure on bank performance: Evidence from Vietnamese banking sector. Int. J. Bus. Perform. Manag. 2016, 17, 184-197. [CrossRef]

2. He, J.; Fu, Q.; Pan, L. Study on the introduction of foreign strategic investors to affect the efficiency of Chinese commercial banks. Chin. J. Manag. Sci. 2010, 18, 49-57. [CrossRef]

3. Liu, M.F.; Zhang, X.L. On the efficiency of commercial banks and its influencing factors under risk constraints. J. Financ. Res. 2013, 7, 113-125. (In Chinese)

4. Yang, W.P. Green economic growth under dual constraints of energy consumption and pollution emission. Mod. Econ. Sci. 2011, 33, 91-98.

5. Jia, L.G.; Lan, X.M. The empirical research into the effects of the ratio of foreign shareholders on the bank competitiveness and financial security in the transition countries of central and eastern Europe. J. Cent. Univ. Financ. Econ. 2007, 12, 30-34. (In Chinese)

6. Lee, C.C.; Hsieh, M.F. Bank reforms, foreign ownership, and financial stability. J. Int. Money Financ. 2014, 40, 204-224. [CrossRef]

7. $\mathrm{Fu}, \mathrm{L}$. Whether the effect of introduction of strategic investors by China's business banks has been overestimated-Rethinking on the effect of foreign equity participation on business banks' management efficiency. Financ. Econ. 2014, 1-10. [CrossRef]

8. Wang, J.D.; Liu, G.R. An empirical study of bank operational efficiency based on foreign capital participation in China's banking industry. Econ. Res. Guide 2010, 77-79. [CrossRef]

9. Li, S.F.; Qiao, G.M. An empirical study of the impact of foreign shareholdings on the operating efficiency of Chinese commercial banks. J. Suzhou Univ. (Philos. Soc. Sci.) 2010, 28, 32-36. [CrossRef]

10. Liu, J.P. The Empirical Study on the Efficiency of Chinese Commercial Banks-Based on DEA and SFA Approach. Ph.D. Thesis, Beijing Jiaotong University, Beijing, China, 2015.

11. Teresienè, D. Performance measurement issues in central banks. Entrep. Sustain. Issues 2018, 6, 176-189. [CrossRef]

12. Charnes, A.; Cooper, W.W.; Rhodes, E. Measuring the efficiency of decision making units. Eur. J. Operational Res. 1979, 2, 429-444. [CrossRef] 
13. Sherman, H.D.; Gold, F. Bank branch operating efficiency: Evaluation with Data Envelopment Analysis. Manag. Sci. Lett. 2014, 9, 297-315. [CrossRef]

14. Lensink, R.; Naaborg, I. Does foreign ownership foster bank performance? Appl. Financ. Econ. 2007, 17, 881-885. [CrossRef]

15. Fethiab, M.D. Assessing bank efficiency and performance with operational research and artificial intelligence techniques: A survey. Eur. J. Oper. Res. 2010, 204, 189-198. [CrossRef]

16. Staub, R.B.; Souza, G.D.S.E.; Tabak, B.M. Evolution of bank efficiency in Brazil: A DEA approach. Eur. J. Oper. Res. 2010, 202, 204-213. [CrossRef]

17. Tone, K. A slacks-based measure of efficiency in data envelopment analysis. Eur. J. Oper. Res. 2001, 130, 498-509. [CrossRef]

18. Chiu, Y.; Chen, Y.; Bai, X. Efficiency and risk in Taiwan banking: SBM super-DEA estimation. Appl. Econ. 2011, 43, 587-602. [CrossRef]

19. Sufian, F. Benchmarking the efficiency of the Korean banking sector: A DEA approach. Benchmark. Int. J. 2011, 18, 107-127. [CrossRef]

20. Chen, C.; Tian, Z.X. Efficiency evaluation of urban commercial bank and inter-regional comparative study. Financ. Econ. 2018, 68-70. [CrossRef]

21. Zhu, F.Y.; Jian, J.C.; Gui, R. Analysis of the operational efficiency of commercial banks under the condition of non-performing loans. Co-Oper. Econ. Sci. 2018, 66-69. [CrossRef]

22. Chen, S.Y.; Wang, L.; Yang, L. The impact of shadow banking activities on bank efficiency: Evidence from Chinese commercial banks. J. Wuhan Univ. 2018, 71, 103-118. [CrossRef]

23. Tonea, K. An epsilon-based measure of efficiency in DEA-A third pole of technical efficiency. Eur. J. Oper. Res. 2010, 207, 1554-1563. [CrossRef]

24. Lee, T.H.; Chih, S.H. Does financial restructuring change the relationship between corporate governance and the static and dynamic efficiency of bank mergers in Taiwan? Emerg. Mark. Financ. Trade 2014, 50, 189-201. [CrossRef]

25. Woo, C.; Chung, Y.; Chun, D.; Seo, H.; Hong, S. The static and dynamic environmental efficiency of renewable energy: A Malmquist index analysis of OECD countries. Renew. Sustain. Energy Rev. 2015, 47, 367-376. [CrossRef]

26. Qin, F.F.; He, X. Research on dynamic efficiency evaluation and influencing factors of China's commercial banks under the background of globalization. Sci.-Technol. Manag. 2013, 67, 105-110. [CrossRef]

27. Chambers, R.G.; Chung, Y.; Färe, R. Benefit and distance functions. J. Econ. Theory 1996, 70, 407-419. [CrossRef]

28. Chung, Y.H.; Färe, R.; Grosskopf, S. Productivity and undesirable outputs: A directional distance function approach. Microeconomics 1997, 51, 229-240. [CrossRef]

29. Zhang, N.; Choi, Y. Total-factor carbon emission performance of fossil fuel power plants in China: A metafrontier non-radial Malmquist index analysis. Energy Econ. 2013, 40, 549-559. [CrossRef]

30. Wang, B.; Wu, Y.R.; Yan, P.F. Environmental regulation and total factor productivity growth: An empirical study of the APEC economies. Econ. Res. J. 2008, 51, 19-32.

31. Kumar, S. Environmentally sensitive productivity growth: A global analysis using Malmquist-Luenberger index. Ecol. Econ. 2006, 56, 280-293. [CrossRef]

32. Li, Z.D.; Yuan, X.L.; Su, Y.B. The assessment for transformation effect of China's economic development models-Based on EBM-Luenberger Model. Financ. Trade Econ. 2017, 38, 21-33.

33. Avkiran, N.K.; Tone, K.; Tsutsui, M. Bridging radial and non-radial measures of efficiency in DEA. Ann. Oper. Res. 2008, 164, 127-138. [CrossRef]

34. Tone, K.; Tsutsui, M. Dynamic DEA: A slacks-based measure approach. Omega 2010, 38, 145-156. [CrossRef]

35. Springer Link. Theory and Calculation of Productivity Indexes. Available online: https://link.springer.com/ chapter /10.1007/978-3-642-79037-9_49\#citeas (accessed on 3 June 2018).

36. Brock, D.M.; Yaffe, T.; Dembovsky, M. International diversification and performance: A study of global law firms. J. Int. Manag. 2006, 12, 473-489. [CrossRef]

37. $\mathrm{Ng}$, A.; Yuce, A.; Chen, E. Determinants of state equity ownership, and its effect on value/performance: China's privatized firms. Pac.-Basin Financ. J. 2009, 17, 413-443. [CrossRef]

38. Fodha, M.; Zaghdoud, O. Economic growth and pollutant emissions in Tunisia: An empirical analysis of the environmental Kuznets curve. Energy Policy 2010, 38, 1150-1156. [CrossRef] 
39. Ji, J.Y.; Kong, D.K. Research on the impact of overseas strategic investors on the operation efficiency of Chinese commercial banks. Econ. Res. Guide 2010, 75-77. [CrossRef]

40. Liu, J.S.; Nie, B.P. The introduction of overseas investor, ownership structure and business performance of commercial bank based on the empirical evidence of 62 commercial banks from 2007 to 2015. Account. Res. 2016, 38, 34-41.

41. Calkins, S. The new merger guidelines and the Herfindahl-Hirschman index. Calif. Law Rev. 1983, 71, 402-429. [CrossRef]

42. Holtz-Eakin, D.; Newey, W.; Rosen, H.S. Estimating vector autoregressions with panel data. Econometrica 1988, 56, 1371-1395. [CrossRef]

43. Arellano, M.; Bond, S. Some tests of specification for panel data: Monte Carlo evidence and an application to employment equations. Rev. Econ. Stud. 1991, 58, 277-297. [CrossRef]

44. Blundell, R.; Bond, S. Initial conditions and moment restrictions in dynamic panel data models. Econ. Pap. 1998, 87, 115-143. [CrossRef]

45. Drake, L.; Hall, M.J.B.; Simper, R. The impact of macroeconomic and regulatory factors on bank efficiency: A non-parametric analysis of Hong Kong's banking system. J. Bank. Financ. 2006, 30, 1443-1466. [CrossRef]

46. Xu, J.X.; Li, N.; Ahmad, M.I. Banking performance of China and Pakistan. Entrep. Sustain. Issues 2018, 5, 929-942. [CrossRef]

47. Wind Database. Available online: http://www.wind.com.cn/ (accessed on 14 August 2018).

48. Zhao, H.Y.; Zhuang, X.M. Research on the ownership structure of commercial banks and corporate governance performance: An empirical analysis based on listed commercial banks in China. North. Econ. Trade 2016, 6, 98-101. (In Chinese)

49. Unite, A.A.; Sullivan, M.J. The effect of foreign entry and ownership structure on the Philippine domestic banking market. J. Bank. Financ. 2003, 27, 2323-2345. [CrossRef]

50. Hu, Y.X.; Qu, X.E.; Zhao, Y.J. Reversed innovation overflow effect of china OFDI-Threshold regression analysis based on provincial panel data. Mod. Financ. Econ.-J. Tianjin Univ. Financ. Econ. 2018, 89, 55-67. [CrossRef]

51. Wu, Z.Y.; Li, F.K.; Li, H.Y. Research on the relationship between diversification and performance of Chinese commercial banks: Based on the perspective of bank size and property. J. Financ. Dev. Res. 2018, 46, 34-41. [CrossRef]

52. Gunawan, R.M.B.; Effendie; Budiarjo, D. The influence of good corporate governance, ownership structure and bank size to the bank performance and company value in banking industry in Indonesia. Eur. J. Bus. Manag. 2014, 6, 9-19.

53. Li, H.M.; Wu, F. Bank scale, cognitive bias and small business financing. Financ. Trade Econ. 2017, 38, 34-50. 